\title{
Red Sea Palaeoclimate: stable isotope and element-ratio analysis of marine mollusc shells
}

\author{
Niklas Hausmann ${ }^{1,2}$, Olga Kokkinaki ${ }^{1}$ and Melanie J. Leng ${ }^{3,4}$
}

${ }^{1}$ Foundation for Research and Technology - Hellas, Institute of Electronic Structure and Laser (IESL), P.O. Box 1527, GR-711 10 Heraklion, Greece

${ }^{2}$ BioArCh, Department of Archaeology, University of York, York YO10 5DD, U.K.

${ }^{3}$ NERC Isotope Geosciences Facilities, British Geological Survey, Nottingham NG12 5GG, U.K.

${ }^{4}$ Centre for Environmental Geochemistry, University of Nottingham, Nottingham NG7 2RD, U.K.

\begin{abstract}
The southern Red Sea coast is the location of more than 4,200 archaeological shell midden sites. These shell middens preserve archaeological and climatic archives of unprecedented resolution and scale. By using shells from these contexts it is possible to link past environmental information with episodes of human occupation and resource processing. This chapter summarises current knowledge about the marine gastropod Conomurex fasciatus (Born 1778) and discusses its use in environmental and climatic reconstruction using stable isotope and elemental ratio analysis. It offers a review of the most recent studies of shell midden sites on the Farasan Islands, their regional importance during the mid-Holocene, theories about seasonal use of the coastal landscape, and preliminary results from new methods to acquire large climatic datasets from $C$. fasciatus shells.
\end{abstract}

\section{Introduction}

On most of the world's coastlines, the exploitation of marine resources in both modern and past societies was and continues to be a common practice with a longstanding tradition (Erlandson 2001). Evidence is found in countless archaeological sites that date far into prehistory and are partly or completely composed of mollusc shells, the food leftovers of the human inhabitants (Cortés-Sánchez et al. 2011; Marean 2014, Steele and Klein, 2008). These 
shell middens feature several characteristics from which archaeological and climatic research benefits. Firstly, the hard shell matrix protects the remains that they cover, such as bones and artefacts (Thomas, 2015a). Secondly, the shell carbonate itself allows for ample material suitable for radiocarbon dating at a high stratigraphic resolution (Stein et al. 2003). And lastly, each individual mollusc shell contains information about the environment in which it grew, because the chemical compositions of shell growth increments are controlled by several environmental factors (e.g. water temperature and salinity). Depending on the growth rate of the shell species, these records can provide daily to centennial information on past environmental conditions (Ridgway et al., 2011). Archaeological shell midden deposits therefore provide dateable, well preserved, high-resolution climate records that are directly related to human activity.

In this chapter, we build on this potential and present studies on the Farasan Island shell midden complex dating to the mid-Holocene $(6-4,000$ cal BP, or calibrated radiocarbon years before the present) and the middens' main constituent, the marine gastropod Conomurex fasciatus (Born 1778). First, we provide a description of the Arabian Neolithic and the sites on the Farasan Islands (Fig. 1). This is followed by an outline of how C. fasciatus shells were used in the past and are preserved today, as well as a description of how it is possible to use shells for environmental and climatic analysis. The section concludes with a modern reference study that focuses on modern $C$. fasciatus and how its shell geochemistry is influenced by the local environment. Second, we describe three applications of the climatic data derived from shell stable isotope and trace element analysis. The section is introduced by a study that compares modern and ancient shells, to assess climatic changes preceding the main occupation period of the Farasan shell middens, which could be linked to the reason why people settled on the islands. Lastly, we also show how short-term seasonal records within individual shells can be used to reconstruct seasonal eating habits of the prehistoric population. We also give prospective on ongoing work involving the use of rapid measurements of elemental ratios in shell carbonate to reconstruct seasonal patterns.

\section{Archaeology}




\section{Regional overview}

The Arabian Neolithic is broadly defined as the prehistoric period linked to specific archaeological sites and lithic artefacts on and from the Arabian Peninsula within the first half of the Holocene. In Arabia, this period is far from being as comprehensively researched as is the case in Europe or the Levant (Edens and Wilkinson 1998; Harrower 2008; Martin et al. 2009; McCorriston 2013). Generally, it is assumed that the Neolithic population of Arabia was much more mobile than its Neolithic counterparts in the north (McCorriston 2013). McCorriston et al. (2002, 2005, 2012; also Crassard et al. 2006) researched the domestication and early herding of cattle in the Wadi Sana (Yemen), and suggested a divide of Neolithic ways of life into people that practised hunting and herding, and people that almost solely relied on herding practices.

In addition to these food procurement strategies, it is now also apparent that a significant portion of the population made use of marine resources (Zazzo et al. 2014). Over 4,000 shell midden sites have been found in the last 15 years (Meredith-Williams et al. 2014b), suggesting that the consumption of marine resources was a way of living that was just as important as herding and hunting. Along the southern Red Sea coastline and on its multitude of islands, people throughout the Holocene took advantage of the rich marine wildlife and collected shellfish in large amounts. The majority of shell remains were found as large middens on the Dahlak Islands, Eritrea, and the Farasan Islands, Saudi Arabia. Many of those sites are large enough to be seen on modern satellite imagery (Meredith-Williams et al. 2014a). In other places, especially the Arabian mainland, middens are less commonly found from satellite imagery and therefore are more likely to be covered by dunes or to be eroded by wadis (Khalidi 2005).

Only a small fraction of middens in the southern Red Sea have been dated. The earliest of these are found on the Eritrean coastline and start at 8,000 cal BP with intermittent occupations continuing to 5,000 cal BP. The earliest sites on the eastern side of the Red Sea date to 7,500 cal BP on the Farasan Islands with almost constant shell accumulation spread over multiple sites between 6,500 and 4,500 cal BP and thereafter intermittent depositions into historical times (Hausmann and Meredith-Williams 2016b; Bailey et al., this volume). 
In addition to Holocene sites, it is assumed that shell middens have been used globally by multiple coastal populations and reach back into periods of (pre-Holocene) lower sea level (Bailey and Craighead 2003). This coastal activity might be, albeit below current sea level, archaeologically very rich (Bicho and Haws 2008; Finlayson 2008; Erlandson et al. 2008; Jerardino 2013; Woodman 2013). Dispersal out of Africa, during the times of lower sea level, makes it likely that there is a plethora, so far undiscovered, of archaeological sites in the underwater areas in the Red Sea (Bailey 2004; Bailey and King 2011; Bailey et al. 2007, this volume; Flemming et al. 2003; Momber 2000, 2004, this volume).

\section{Farasan Island shell midden complex}

Earlier research studies on the Farasan Islands tried to find suitable Palaeolithic (PleistoceneHolocene) sites to identify the possible migration out of Africa through a southern pathway (Bailey et al. 2014a, b, this volume). The location of the Farasan Islands on the eastern shore of the Red Sea, and possible connections to other islands, makes them a favourable destination for hominids crossing from Africa to Arabia.

Investigations on land provided several unstratified localities that are likely to be related to the Palaeolithic, but no dateable material from this period was identified. Nearly 3,000 shell midden sites were found, ranging from the mid-Holocene to Islamic periods. The structural preservation of thousands of sites is likely mainly due to the lack of urban development in the area until recently. Generally, shell middens are destroyed by construction workers as shells provide an easily accessible construction material, despite the archaeological remains within them, which often include human bones.

The unexpected richness of the archaeological material, as well as the increasing urban development on Farasan potentially leading to their destruction, has shifted research focus to these sites and triggered multiple excavations in 2004, 2006, 2008, 2009, 2012 and 2013 (Alsharekh and Bailey 2014) (Fig. 2). More than 20 shell middens have been excavated as well as 71 test pits along major palaeo-shorelines on the large islands of the archipelago: Farasan Kabir, Qumah and Saqid (Bailey et al. 2014a, b, this volume). 
Shell middens occur along modern shorelines and palaeo-shorelines, which have been tectonically uplifted in some areas. The association with specific shorelines, and hence specific sea-levels, allows a tentative assignment of the same date to sites sharing the same shoreline (Meredith-Williams et al. 2014).

One particular site has been analysed in significant detail. Site JW1727 is located in the uplifted western part of Janaba Bay (Fig. 3). It is part of a large group of shell middens along one palaeoshoreline, and is part of a line of middens that follow the direction of sea level change. While JW1727 itself is approximately $0.75 \mathrm{~km}$ away from the modern shoreline, there are dozens of smaller sites in between, dating to progressively younger periods, the closer they get to the current sea level (Hausmann and Meredith-Williams 2016b).

JW1727 dates to 4,800 cal BP and contains a large accumulation of shells that were deposited over a very short time period (0-88 years, $95.4 \%$ probability, Hausmann and MeredithWilliams 2016a). Over the course of less than a century, people collected living specimens of C. fasciatus in addition to other mollusc species (predominantly Pinctada sp. and Arca avellana) as food. It is likely that the warm shallow water areas of Janaba Bay were an amenable environment for molluscs and facilitated the large and constant supply of marine protein for humans inhabiting the shoreline. The now uplifted part of Janaba Bay would have provided shellgathering grounds of several square kilometres that were easily accessible to the prehistoric populations.

The archaeological record does not provide clear evidence of how the molluscs were processed after collection. It is likely that they were gathered close to the waterfront and heated in bulk, using non-permanent hearths, often on top of previously cooked shells, as evidenced by thin layers of ash and charcoal, which are often found between layers of shells (Hausmann et al. 2015b). Heating causes the animal to detach from its shell, thus extracting the meat becomes much easier. It is likely that people made use of this effect, although it has not yet been possible to confirm this from evidence of heating on the shell surface.

Mineralogical changes from aragonite to calcite can occur when shells that contain aragonitic calcium carbonate are being heated, because the rise in temperature causes the mineral 
composition to change from aragonitic to calcitic, as aragonite is thermodynamically unstable (Sand et al. 2012). However, Raman spectroscopy on archaeological C. fasciatus shells did not observe changes in mineralogy (Hausmann et al., 2015b). Significant mineral changes depend on the duration and temperature of the cooking process. Small shells like C. fasciatus can be cooked within a few minutes in boiling water, which is unlikely to be enough to cause any measurable changes in the mineral or isotopic composition (Milano et al. 2016).

There is little evidence of processing tools or cooking equipment in the archaeological remains at JW1727. Some pottery material, in the form of a small sherd, has been found (Hausmann et al. 2015b), but it is unclear how pottery was used or if it was part of the shell processing activities. Since preservation conditions are generally good, it is possible that shellfish processing happened at a different location and JW1727 was only a waste dump for shells. It is also possible that processing was undertaken on site but artefacts involved were deposited elsewhere and are perhaps more likely to be found in connection with habitational sites. Habitational sites are not preserved on Farasan, possibly as they would have lacked protection from soil erosion. As such, middens are the primary source of archaeological information on the Farasan Islands. Furthermore, since few middens are found outside Farasan in Arabia, they are also some of the most important archaeological sites in the region. There is evidence of similar patterns of shell midden sites on the western side of the Red Sea, suggesting that the Farasan islands are not simply an anomaly found in Arabia, but are a result of the richness of the Red Sea environment, the coastal dynamics of the tectonic landscape, and the efficiency of the coastal exploitation patterns that led to the construction of the shell mounds.

\section{Shell midden calcium carbonate as an environmental proxy}

\section{C. fasciatus stable isotope geochemistry}

Here, we combine sclerochronology, the study of physical variations in the accretionary hard parts of marine organisms (Butler and Schöne, 2017), with the measurement of stable isotopes of this same material. Specifically, we measured the ratios ${ }^{18} \mathrm{O} /{ }^{16} \mathrm{O}$ and ${ }^{13} \mathrm{C} /{ }^{12} \mathrm{C}$. These ratios may vary according to external environmental or internal metabolic factors 
(Cusack and Freer, 2008; Wanamaker et al., 2007), and are used as a well-constrained method in archaeological science (Andrus, 2011; Leng and Lewis, 2016; Schöne and Gillikin, 2013).

Growth increment formation in molluscan shells follows a biochemically complex process that mainly includes the formation of calcium carbonate and organic material during aerobic and anaerobic states of the metabolism. In the state of aerobic metabolism, molluscs deposit calcium carbonate in the form of aragonite or calcite in combination with organic material enclosed within the shell structure (Lutz and Rhoads, 1977). The resultant mineralogy is specific for each mollusc species and can both occur on its own (i.e., all aragonite or all calcite), mixed together (i.e., alternating aragonite and calcite bands) or separated into different parts of shells (Leng and Lewis, 2016).

Molluscs precipitate their shell layers $\left(\mathrm{CaCO}_{3}\right)$ and acid $\left(\mathrm{H}^{+}\right)$by the following chemical reaction:

$\mathrm{Ca}^{2+}+\mathrm{HCO}_{3}{ }^{-} \rightleftarrows \mathrm{CaCO} 3+\mathrm{H}^{+} \quad$ (Equation 1$)$

The aerobic metabolism is associated with periods when molluscs are exposed to welloxygenated waters, such as at high tide, and when the shell is open. In contrast, in times of anaerobic state (i.e. shell closure) the amount of acidic components in the shell-building fluids rises and is gradually neutralised by the calcium carbonate of the shell, resulting in the dissolution of calcium carbonate and a larger amount of organic material content in the layer deposits (Crenshaw 1980;Lutz and Rhoads, 1977)).

Many other factors can play a role in the changing precipitation patterns of calcium carbonate. Extreme events like spring tides, storms, or high temperatures can affect a mollusc's metabolism and can cause it to rapidly convert into an anaerobic state and result in hiatuses in the isotopic record. Changes linked to the physiology of a mollusc are equally important. Stress such as spawning events (Kennish, 1980) and the availability of food can have a significant influence on gastropod shell growth (Schöne, 2008). 
There is a theoretical and empirical relationship between ${ }^{18} \mathrm{O} /{ }^{16} \mathrm{O}$ (expressed in reference to established standards as $\delta^{18} \mathrm{O}$ ) of the shell carbonate and temperature due to equilibrium fractionation. The higher/lower the ratio the colder/warmer the temperature, so long as the oxygen isotope composition of the seawater remains constant (Grossman and $\mathrm{Ku}, 1986$ ). Seawater is isotopically heavier than freshwater so rivers and streams entering the coastal environment can affect shell $\delta^{18} \mathrm{O}$. The oxygen isotope ratio of shells is a record of the environment over a mollusc's lifetime, which can then be analysed to produce a local environmental record. Shell $\delta^{18} \mathrm{O}$ can thus allow for the calculation of temperature or salinity (by way of empirical $\delta^{18} \mathrm{O}$-salinity relationships) of surrounding waters, the seasonal variations of either of these, and long-term changes related to climatic or oceanographic changes.

Here we use $\delta^{18} \mathrm{O}$ values from aragonitic shells of $C$. fasciatus (hereafter called $\delta^{18} \mathrm{O}_{\mathrm{S}}$ ), and the empirically derived temperature equation of Grossman and $\mathrm{Ku}$ (1986), adjusted for the $\delta^{18} \mathrm{O}$ of collected modern sea water (hereafter called $\delta^{18} \mathrm{O}_{\mathrm{W}}$ ) (Dettman et al. 1999), to estimate the Sea Surface Temperature (SST) at the Farasan Islands for the moment of shell growth.

$\operatorname{SST}\left({ }^{\circ} \mathrm{C}\right)=20.6-4.34\left(\delta^{18} \mathrm{O}_{\mathrm{S}}-\left(\delta^{18} \mathrm{O}_{\mathrm{W}}-0.27\right)\right) \quad$ (Equation 2$)$

\section{Modern seawater isotopic composition and temperature measurements}

In order to calibrate Equation 2 for $C$. fasciatus we compared modern measured temperature and $\delta^{18} \mathrm{O}$ of seawater with modern shell $\delta^{18} \mathrm{O}$. Local measurements of temperature and salinity were taken over a 1.5-year period using two data loggers (Star Oddi DST CTD) to investigate the local environment around Farasan, and to confirm that the archipelago follows the pattern of the regional climate or experiences any local anomalies (Fig. 4). These were then combined with the Sea Surface Temperature (SST) and Sea Surface Salinity (SSS) data that were accessible via the National Oceanic and Atmospheric Administration (NOAA). The data were measured hourly by a GLOBAL-HYCOM remote sensor (available for the Farasan Islands (FARS1) at http://ecoforecast.coral.noaa.gov/index/0/FARS1/station-home). Temperatures are reported in ${ }^{\circ} \mathrm{C}$ and salinity in practical salinity units (psu), which is equivalent to parts per thousand. 
Results show a significant change in SST throughout the year in an overall range of about $7-$ $8^{\circ} \mathrm{C}$, which translates into a $\sim 2 \%$ change in estimated $\delta^{18} \mathrm{O}\left(\delta^{18} \mathrm{O}_{\text {Est. }}\right)$. The change is regular and occurs at similar times of the year, with little variation between the different years or measurement locations (Fig. 4). The seasonal salinity changes are similarly consistent from one year to another. However, they have a range of only 2 psu. This nearly constant salinity is likely to be due to the generally low precipitation throughout the year and thus low amounts of fresh water that enter the coastal bays. However, fresh water inflow from ocean currents can have a strong impact on the $\delta^{18} \mathrm{O}_{\mathrm{W}}$ values of the local marine water and needs to be accounted for. Water samples from Janaba Bay and eight other sites around Farasan were analysed in order to assess spatial differences and to explore the water exchange in different parts of the research area.

Because the salinity values from the NOAA record seem to coincide with the inflow of surface water from the Indian Ocean for the autumn and winter months, which is less saline than Red Sea surface water (Raitsos et al., 2013), it is possible that this inflow has an influence on the $\delta^{18} \mathrm{O}_{\mathrm{W}}$ of the marine water around Farasan. This issue requires further investigation since it may substantially affect the $\delta^{18} \mathrm{O}_{\mathrm{S}}$ record of $C$. fasciatus shells - both modern and archaeological.

The comparison of $\delta^{18} \mathrm{O}_{\mathrm{W}}$ from different study areas around Farasan, showed how evaporation fractionation can vary spatially and helped to single out areas with little variability to produce more precise estimates of past climate changes. $\delta^{18} \mathrm{O}_{\mathrm{W}}$ values from spring (May) and winter (December) were used to compare the way different locations are being affected by evaporation (Fig. 5). Spatial analysis was performed by interpolation of stable $\delta^{18} \mathrm{O}_{\mathrm{W}}$ isotope data from different locations. Subsequently, they were used to calculate a raster through an inverse-distance-to-power-method (IDW). This method estimates values between sample locations in accordance with the values of nearby samples. The colouring of areas is arbitrary and the range is based on the minimum and maximum of the isotopic values that were used for the calculations. This isotope distribution-map is only preliminary and it can be significantly improved by adding more data from other areas in order to achieve a more detailed analysis.

The isotope distributions corresponding to May and December differ significantly. While the May samples are more homogenous, the December samples show distinct differences in 
isotopic values between sites that are directly exposed to the Red Sea marine water and sites that are more enclosed. The enclosed sites experience less water exchange and hence are more susceptible to fractionation due to evaporation. Evaporation is increased during the summer with higher temperatures and no precipitation. This aspect of the spatial differences in isotopic composition around Farasan is an especially important consideration for comparisons of shell carbonate from archaeological sites that are not from the same areas within the islands. It is likely that the shells growing in more enclosed waters experienced a relative increase of $\delta^{18} \mathrm{O}$ during summer, similar to the water samples above.

Overall, the stable isotope data from the marine water samples strengthens the assumption that no major influences from other water sources are present and that the change in temperature is the dominant factor that affects the $\delta^{18} \mathrm{O}$ recorded in the shell carbonate. The overall isotopic landscape of Farasan reflects evaporation and surface water exchange with the surrounding Red Sea. However, the modern marine environment of Janaba Bay, the main location of the archaeological studies, is not significantly affected by evaporation, and exhibits sufficient exchange with the open water to avoid anomalies. As a result of these findings, the $\delta^{18} \mathrm{O}_{\text {est }}$ dataset, based on the local environment of the $C$. fasciatus shell, provided a simple baseline for the examination of the shell carbonate as a proxy for palaeotemperature.

\section{Biology of $C$. fasciatus}

Comprehensive studies of $C$. fasciatus (Fig. 6) are scarce and much information has been drawn from other species of the Conomurex and Strombus genera under the assumption that they share a similar shell anatomy and ontogenesis. A common characteristic of Strombus shells is the characteristic lip, which grows on the aperture when they reach adulthood. The presence of the lip is used as a way of distinguishing juvenile and adult parts of the shell, the main body (=juvenile) and the lip on the aperture of the shell (=adult).

C. fasciatus is a herbivore that feeds on detritus and algae. It is adapted to the warm climate and the highly salinity of the Red Sea. Adult specimens range in sizes between $25 \mathrm{~mm}$ and 50 $\mathrm{mm}$ in length. It is generally thought that this species prefers to live on fine sediment in calm waters (Sharabati 1984), although this does not coincide with our experience during 
collection. Around the Farasan Islands we found that live specimens of $C$. fasciatus were most abundant in areas with little vegetation and sand, and were subjected to heavy wave action.

Modern specimens of C. fasciatus were collected during 2012, 2013 and 2014 (Hausmann 2015). From earlier research (Bailey et. al 2013) it was known that the animal can be present in large numbers and groups of 50 have been seen on Soulayn Island, northeast of Farasan Kabir. In comparison, the coastline of Janaba Bay has smaller colonies of $C$. fasciatus. Live specimens were found in an area near the JE0004 shell mound. Many fruitless expeditions were carried out all around the islands, looking at different types of shorelines and microenvironments, despite help from local fishermen and members of the coast guard. Apart from the location near JE0004 only a beach north of Seir village in the northwest of Farasan Kabir had $C$. fasciatus specimens present. Both sites were exposed to heavy wave action and had little to no sand cover over a rough coral bedrock. Underwater vegetation was present but not in large quantities, although this varied with the season. Summer months had very little vegetation, while winter months had more extensive vegetation.

Over the course of several seasons, an experiment was carried out to observe the stable isotope composition of shells from molluscs that died at different times of the year. By solving Equation 2 for the $\delta^{18} \mathrm{O}_{\mathrm{S}}$ value using known values for temperature and $\delta^{18} \mathrm{O}_{\mathrm{W}}$, we can estimate the $\delta^{18} \mathrm{O}$ values in shells (hereafter $\delta^{18} \mathrm{O}_{\text {est }}$ ) and create a baseline (Fig. 4, grey area). We can then compare the $\delta^{18} \mathrm{O}_{\mathrm{S}}$-value of the collected modern shell to the $\delta^{18} \mathrm{O}_{\text {est }}$, and assess the use of the shell carbonate of $C$. fasciatus as a proxy for palaeotemperature. In total, we collected 16 live specimens with at least two specimens per season. Their shells were cleaned and the $\delta^{18} \mathrm{O}_{\mathrm{S}}$-value of the most recent growth increment was measured (Hausmann et al. 2015a). The last growth increments are found at the ventral margin and are likely to have grown in the 1-2 weeks before sampling.

Shell-edge $\delta^{18} \mathrm{O}_{\mathrm{S}}$ values of the 16 shells ranged from $-0.5 \%$ to $-1.7 \%$ o between February (winter) and September (autumn), respectively. For each collection date we calculated the $\delta^{18} \mathrm{O}_{\text {est }}$ value and compared it to the measurements of the corresponding season. The estimated values showed a very good agreement with the actual measurements of $\delta^{18} \mathrm{O}_{\mathrm{S}}\left(\mathrm{R}^{2}=\right.$ 
0.88) revealing that $C$. fasciatus form the shells close to or in isotopic equilibrium with the ambient water (Fig. 7) according to Eq. 2. This suggests that we can use well-preserved archaeological shell $\delta^{18} \mathrm{O}$ values to reconstruct temperature ranges.

\section{Applications for $C$. fasciatus as a climate proxy}

\section{Introducing three case studies}

Building on the archaeological background and the study of $\delta^{18} \mathrm{O}$ records in modern specimens of $C$. fasciatus, we briefly describe three recent case studies. The first study compares the isotope composition of shells from two periods of occupation on Farasan to investigate if they reflect the climatic changes found in other palaeoclimate proxies from Arabia (Hausmann et al. 2015b). This approach combines data from different temporal resolutions and integrates short-term archaeological 'snapshots' with the long-term records from marine cores or stalagmites. The second study employs the sub-annual records of individual shells to determine the time of year the shells were being exploited (Hausmann and Meredith-Williams 2016b). This technique can be applied to the study of the mobility of human populations as well as to reconstruct accumulation rates and seasonal structure of the shell matrix. The third study presents preliminary elemental ratio data in C. fasciatus shells and discusses this type of data as a means of assessing environmental change.

\section{Comparison of modern and mid-Holocene climates}

The majority of the Farasan shell middens accumulated during a period from 6,500 to around 4,500 cal BP (Bailey et al. 2013, this volume). This period is on the border of a climatic change from a humid to a more arid climate between 8,000 and 6,000 cal BP, covering the north of Africa, Arabia and parts of India (Adamson et al. 1980; Arz et al. 2003; Fleitmann et al. 2007; Gasse 2000; Hoelzmann et al. 1998; Pachur and Kröpelin 1987; Rossignol-Strick 1983, 1985; Van Campo et al. 1982). For human populations, this change in climate seemed to cause a shift in population densities and subsistence strategies, which were inherently linked to the annual summer monsoon transporting water from the Indian Ocean to the inland areas, precipitating regularly and intensively and providing life sustaining conditions for 
central Arabia (Lezine et al. 2010). In detail, the humid conditions in the early Holocene are associated with a northward displacement of the summer monsoon due to a shift in the intertropical convergence zone (ITCZ) to $23^{\circ} \mathrm{N}$ (Biton et al. 2010). The influence can be seen in the large number of environmental records available from wetlands and lakes from all over Arabia. From this climate optimum to 5,000 cal BP, a climatic deterioration is seen in lacustrine and spring deposits (Lézine et al. 2014). The marine records of aeolian dust transported from arid areas and deposited in the Arabian Sea (KL74; Sirocko et al. 1993) also show an increase of sand deposition around 7,000 cal BP after a 3,000-year period of less sand deposition. Van Rampelbergh et al. (2013) compared different proxies from the southern Arabian Peninsula and found a gradual change toward arid landscapes at around 7,000 cal BP for the Yemeni lowlands and for the Yemeni highlands at 5,000 cal BP. This is contrasted by an abrupt change in salinity from 7,000 to $6,500 \mathrm{cal} \mathrm{BP}$ found in $\delta^{18} \mathrm{O}$ records of planktonic foraminifera Globigerinoides ruber from the northern and the central Red Sea (Arz et al. 2003).

Archaeological shells of $C$. fasciatus on Farasan were used to provide a local marine record for this long-term climate change seen elsewhere in Arabia. Two shell middens sites, JE0087 and JW1727, dated to 6,500 cal BP and 4,800 cal BP, respectively were used. Comparing the $\delta^{18} \mathrm{O}$ of shells from both sites provides insight into when climate change occurred around Farasan. The above climatic data also shows a change from humid to a more arid environment over this period and is perhaps the cause of the large-scale shellfish exploitation that happened during the occupation of JW1727.

For the isotope analysis, sequential carbonate samples were drilled from the shell edge to the protoconch (the very first increments of shell growth). The range of $\delta^{18} \mathrm{O}_{\mathrm{S}}$ values from shells collected from JE0087, JW1727, and the modern environment were compared. Shells from around $6,500 \mathrm{cal} \mathrm{BP}$ showed $\delta^{18} \mathrm{O}_{\mathrm{S}}$ ranging from $-0.1 \%$ to $-1.9 \%$, shells from $4,800 \mathrm{cal} \mathrm{BP}$ showed $\delta^{18} \mathrm{O}_{\mathrm{S}}$ ranging from $-0.2 \%$ to $-2.2 \%$, while the modern shell $\delta^{18} \mathrm{O}_{\mathrm{S}}$ ranged from $0.3 \%$ to $-2.8 \%$. These ranges in $\delta^{18} \mathrm{O}$ are fairly similar, although the modern values have a slightly wider range and have slightly lower average values. This difference might imply a lower seasonal contrast, as well as cooler summers in archaeological times compared to 
today, assuming the isotope composition of the seawater was constant.

Other records suggest a decline in relative humidity connected to the southward displacement of the ITCZ between 7,000 and 6,000 cal BP (Fleitmann et al. 2007). Accordingly, Arz et al. (2003) found an increase of $\delta^{18} \mathrm{O}$ values from $-0.6 \%$ to $-1.0 \%$ in the Gulf of Aqaba and from $-0.6 \%$ to $-1.4 \%$ outside the Gulf of Aqaba in the North of the Red Sea, by measuring planktonic foraminifera (Globigerinoides ruber) from sediment cores. But on Farasan the average $\delta^{18} \mathrm{O}_{\mathrm{S}}$ change is insignificant between $6.5 \mathrm{kyr}$ cal BP $(-1.1 \%$ o $)$ and $4.8 \mathrm{kyr}$ cal BP ($1.2 \%$ ). Equally puzzling, the average $\delta^{18} \mathrm{O}_{\mathrm{S}}$ found in Farasan shells decreases by $0.3 \%$ o between the mid-Holocene and now, indicating an increase in humidity or warmer temperatures. It should be noted that our $\delta^{18} \mathrm{O}$ data are from the coastal environment and the foraminifera from the open ocean. In recent times Raitsos et al. (2013) have shown that the Farasan Islands are in an area where temperatures have increased dramatically since 1994 $\left(+0.8^{\circ} \mathrm{C}\right.$ when comparing two time frames of $1985-1993$ and 1994-2007). A temperature increase of $+0.8^{\circ} \mathrm{C}$ would decrease $\delta^{18} \mathrm{O}_{\mathrm{S}}$ by $\sim 0.2 \%$ and would be enough to explain the lower values found in the modern shells.

In summary, the shell carbonate from the two archaeological periods does not indicate large climatic variations, implying that the amount of precipitation and the overall aridity of the environment of both periods was likely to have been very similar. There is no indication of a less rich marine environment and it was likely similarly productive throughout the Holocene. Based on the stable isotope data, it is likely that there has been no dramatic environmental change between the small-scale exploitation that is represented in the first layers of JE0087 and the large-scale exploitation represented by JW1727. The gradual change to an arid environment over several thousand years that was found in some studies (Fleitmann et al. 2007; van Rampelbergh et al. 2013) was not as evident as the abrupt change around 7,000 cal BP that was found in others (Arz et al. 2003; Sirocko et al. 1993). Following this it is more likely that the Tihama lowlands and also Farasan became arid much earlier and more rapidly than the highlands.

\section{Seasonality study of archaeological shells}


The isotope record in C. fasciatus can also be used to analyse seasonality. For this we analysed a sequence of shells from the shell mound JW1727. Individual shell records indicate seasonal minima and maxima in the water temperature (assuming no change in the oxygen isotope composition of the water), and the terminal value of the shell (at the aperture) may provide and indication of the season when the mollusc was captured (Thomas, 2015b). From this we are able to draw general conclusions about how the ancient Farasan people carried out shellfish exploitation. Shells from five layers in the midden were selected and, where possible, grouped in stratigraphic sequence (top, centre, base). It was only possible to determine the season of death of 66 of the 86 analysed specimens. In some cases the exact season of death (winter, spring, summer, autumn) was not distinct, in which case we grouped them in an intermediate seasonal group (winter-spring, spring-summer, etc.).

The results from all stratigraphic levels show that the shellfish were collected throughout the year (Fig. 8), although more were collected in the arid summer/autumn months. It is perhaps not surprising that the southern Red Sea with its subtropical environment and general richness in marine wildlife provided year-round coastal resources. In contrast, the summer aridity of this region and the seasonally negative effect on the terrestrial vegetation is perhaps why there was an increase in shellfishing during the warmer seasons.

In layer 8 , there is a change in the season of collection (spring to autumn) from the base to the top (Hausmann and Meredith-Williams 2016a) suggesting that the layer is likely to have accumulated over a year or so as the season of collection is progressive, rather than the layers being formed from several unconnected seasons in different years. The length of the period that is covered by the sequential seasons, combined with the size of the layer, results in an accumulation rate that suggests a temporal scale of weeks and months.

Furthermore, we can use the fact that the analysed shells in layer 8 lived at the same time and that their records cover the same years. Hence, any variation from one specimen to another is due to the variation of how individual mollusc specimens record temperature and how the temperature varies within their shared habitat. This provides a good estimate of how accurate temperature estimates are that are based on this species in this area. Without the shells' stratigraphic and seasonal relation, any differences in their records could be due to variations 
between the different years in which the molluscs grew.

Lastly, by stratigraphically grouping shells of the same season of death and connecting other archaeological remains to them, it is possible to give more meaningful interpretations to the archaeological deposit and artefacts within it. One of the conditions for providing a temporal scaffolding like this is a large amount of specimens (dozens to hundreds) to be analysed from a small area within the deposit. This directly translates into research costs and is difficult to carry out using the methods applied above.

\section{Preliminary data on $\mathrm{Mg} / \mathrm{Ca}$ and $\mathrm{Sr} / \mathrm{Ca}$ ratios as palaeothermometer proxies for $\mathrm{C}$.}

\section{fasciatus}

Here we provide preliminary data on elemental ratios in $C$. fasciatus shells and discuss their potential as a climate proxy. Generally, the incorporation of $\mathrm{Mg}^{2+}-$ or $\mathrm{Sr}^{2+}$-ions in relation to $\mathrm{Ca}^{2+}$-ions into calcium carbonate has been proposed as a proxy for palaeotemperature (Elderfield and Ganssen, 2000; Watanabe et al., 2001). However, specifically in mollusc shells elemental ratios have been analysed with mixed success and were largely shown to not be as reliable as stable isotope values (i.e. $\delta^{18} \mathrm{O}$ ) for temperature reconstruction (Cusack and Freer, 2008). Most mechanisms of shell precipitation are not universally applicable to all shell species and seldom apply without variation between species or specimens of the same species (e.g. Graniero et al. 2017). Nevertheless, elemental ratios have the advantage that they can be assessed very quickly (Cobo et al., 2017; Durham et al. 2017; Giakoumaki et al., 2007) and can easily be analysed in the form of spatially detailed maps (Cáceres et al., 2017; Hausmann et al., 2017). Additionally, fast analyses have the benefit of lower costs for individual samples, which can result in larger archaeological datasets of seasonal coastal exploitation. The Farasan Island shell middens with over 3,000 sites and thousands of cubic meters of shell are a good example of a large shell assemblage and the immense amount of time and money that can be required for its study. As shell seasonality analysis becomes more established in archaeology, the weaknesses of studies that are too small are becoming more apparent (Thomas 2015b). For instance, Jew et al. $(2013,2014)$ showed that $35 \%$ of seasonal signals were falsely interpreted due to small sample numbers of analyses performed on 
individual shells. Also, Hausmann and Meredith-Williams (2016a) showed the loss of information when analysing small numbers of shells per stratigraphic unit.

To work towards larger shell seasonality datasets, we use the ability of rapid elemental mapping through Laser Induced Breakdown Spectroscopy (LIBS) to assess $\mathrm{Mg} / \mathrm{Ca}$ and $\mathrm{Sr} / \mathrm{Ca}$ ratios in C. fasciatus as potential palaeoclimate proxies for the Farasan Islands. To achieve this, we selected archaeological specimens that had previously been analysed using stable oxygen isotopes, to provide a comparative framework.

LIBS is a simple, straightforward and versatile technique for rapid analysis of the chemical composition of a huge variety of materials. It is based on the atomic emission spectroscopy of plasma, generated by focusing a high intensity (in the order of $\mathrm{GW} / \mathrm{cm}^{2}$ ) laser beam onto the material. The plasma emission is collected and is spectrally resolved, thus, providing qualitative and quantitative results by monitoring the emission line intensities of the chemical constituents of the material. LIBS has been shown to have significant potential in environmental studies (Harmon et al. 2005; Marín-Roldán et al. 2014; Qiao et al. 2015). The method presents many advantages over conventional analytical techniques, such as the ability to perform in situ measurements without any sample preparation, nearly instantaneous measurement time and easy-to-use equipment of low-maintenance cost. Hence, it is possible to carry out a multitude of measurements with a high spatial resolution and within a small period of time (one measurement takes a few seconds). For all these reasons, LIBS appears to be the most promising technique for the rapid analysis of the vast number of shell middens.

Sample preparation for LIBS is minimal and because the analysed shell specimens were used in earlier studies (Hausmann and Meredith-Williams, 2016a, b), cleaning and sectioning of the shells was already finished. However, LIBS analysis benefits from flat sample surfaces, which is why it was necessary to regrind the samples using metallographic grit paper (P800) and to remove any holes left by previous sampling steps.

The experiments were carried out using the LIBS setup described in Hausmann et al. (2017), which can be used to provide maps of elemental ratios with a resolution of $\sim 90 \mu \mathrm{m}$. However, sample locations were measured using single pulses instead of 10 to achieve a faster acquisition speed. Single pulse analysis has been shown to provide sufficiently accurate information on $\mathrm{Mg} / \mathrm{Ca}$ ratios in elemental maps of carbonates (Cáceres et al., 2017). 
To assess the ratios of $\mathrm{Mg}$ and $\mathrm{Sr}$ towards $\mathrm{Ca}$, we measured the peak intensity ratios of the respective emission lines with the wavelengths of $279.55 \mathrm{~nm}(\mathrm{Mg}$ II), $407.77 \mathrm{~nm}$ (Sr II), and $317.93 \mathrm{~nm}$ (Ca II). Intensity values of $\mathrm{Mg}$ and $\mathrm{Sr}$ were then divided by the intensity value of $\mathrm{Ca}$, to provide an intensity ratio that is proportional to the absolute concentration of $\mathrm{Mg} / \mathrm{Ca}$ and $\mathrm{Sr} / \mathrm{Ca}$.

Four shells from the shell midden JW1727 were analysed (Sample ID: JW1727-8-T-2, JW1727-8-M-12, JW1727-8-M-13, for clarity now samples A, B, C, respectively). All specimens previously provided a $\delta^{18} \mathrm{O}$ record of seasonal temperature change (Fig. 9). The $\delta^{18} \mathrm{O}$ values produced records of temperature change of varying length, covering different seasons of the year. Due to the short time period covered by the individual shell records, a more detailed annual overview of elemental composition was not possible. Shell A covers a period of summer until late autumn or early winter based on the $\delta^{18} \mathrm{O}$ values. $\mathrm{A} \mathrm{Mg} / \mathrm{Ca}$ line scan following the direction of growth shows an increase of $\mathrm{Mg} / \mathrm{Ca}$, a plateau phase and a subsequent drop of $\mathrm{Mg} / \mathrm{Ca}$ towards the shell edge. This is not reflected in all parts of the analysed shell, as is shown by the mapped values. The variation within coeval parts of the shell increments is as high as the variation covered by the line scan, suggesting that $\mathrm{Mg} / \mathrm{Ca}$ intensity ratios are not controlled by a time-resolved factor (i.e. environmental change). The same results apply to $\mathrm{Sr} / \mathrm{Ca}$ line scans and elemental maps. More specifically, exterior parts of the shell aperture seem to be more enriched in $\mathrm{Sr}$ than coeval interior parts of the same growth increment. Additionally, the error of individual sample locations is almost as large as the overall variation of $\mathrm{Sr} / \mathrm{Ca}$ intensity ratios in the whole, making it difficult to assess any seasonal change in the record.

Shell B covers a longer time span of over one year, based on the $\delta^{18} \mathrm{O}$ values. While the $\mathrm{Mg} / \mathrm{Ca}$ line scan shows several $\mathrm{Mg}$ enriched areas that far exceed the range of intensity ratios measured in shell A, they were not in agreement with $\delta^{18} \mathrm{O}$ values. Moreover, the elemental map of shell $\mathrm{B}$ shows the spatial variability of $\mathrm{Mg} / \mathrm{Ca}$ intensity ratios and the inconsistency of enriched areas in regards to following the structure of growth increments. This is most prominent in the thin part of the whorl grown prior to the shell lip, where high and low $\mathrm{Mg} / \mathrm{Ca}$ intensity ratios grow in parallel. $\mathrm{Sr} / \mathrm{Ca}$ intensity ratios show a larger variation than in shell $\mathrm{B}$, however are not corresponding to $\delta^{18} \mathrm{O}$ values. The mapped $\mathrm{Sr} / \mathrm{Ca}$ data shows a general enrichment in the central part of the shell aperture, however this enrichment does not persist to the interior or exterior parts of the shell. 
Shell C produced similar results to shells A and B, with little correlation of stable isotope values and elemental intensity ratios. The $\mathrm{Mg} / \mathrm{Ca}$ line scan shows almost no variation, with a slight decrease towards the shell edge and a single enriched area at about $2 \mathrm{~mm}$ distance to the shell edge. This increase is tentatively mirrored by the $\delta^{18} \mathrm{O}$ values. The map of $\mathrm{Mg} / \mathrm{Ca}$ intensity ratios, shows that the enriched area intensifies towards the shell edge but largely follows the constrains of the growth increment. Considering the lack of responses of $\mathrm{Mg} / \mathrm{Ca}$ intensity ratios in C. fasciatus to environmental change, it is likely that this time-resolved increase reflects a stop in shell growth. This results in organically rich growth increments, that have an increase concentration of $\mathrm{Mg}$ (Schöne et. al, 2010). However, this enrichment is not reflected in $\mathrm{Sr} / \mathrm{Ca}$ intensity ratios, which do not show any change despite a first gentle and then sharp increase towards the shell edge.

The elemental analyses presented here are preliminary, but largely indicate that $\mathrm{Mg} / \mathrm{Ca}$ and $\mathrm{Sr} / \mathrm{Ca}$ ratios in $C$. fasciatus do not reflect the environmental changes experienced by the animal and cannot be used as palaeothermometer. Responses of elemental ratios to environmental changes are various but ideally show regularly repeating patterns (Warter and Müller, 2017). These patterns are entirely missing from our samples. Moreover, in all shells the spatial patterns of elemental ratios largely did not follow the structure of growth increments and thus were not consistently connected to the increments' times of growth or connected to environmental changes or events happening at specific times or over certain periods.

Equally, most growth increments produced values of high and of low elemental ratios, reflecting larger spatial patterns that were not restricted by the extents of the growth increments they are part of. These spatial patterns were not as predictable as has been shown in other shell species, that had 'preferred' sampling zones, which predictably provided more consistent results (Lazareth et al., 2013).

Stable oxygen isotope values indicate that the analysed areas are records of one year or less, which would explain the lack of patterns that occur annually. However, the missing correlation between the stable oxygen isotope values and elemental ratios shows that even sub-annual temperature changes are not reflected in the elemental ratios and that determining the season of harvest is not possible.

Elemental ratios and the degree to which they reflect changes in ambient temperature can change throughout the lifetime of the mollusc (Freitas et al., 2005). In this study we solely 
sampled adult sections of $C$. fasciatus shells, as they contained the sampling locations for the stable isotopes analysis, which aimed to determine the mollusc's season of death. Thus, we cannot claim that elemental ratios consistently do not reflect changes in temperature. However, in the areas of the shell that contain information important to seasonality studies (i.e. the aperture lip), it is evident that elemental ratios cannot be used as a temperature proxy. LIBS analysis potentially covers all elements and future analyses should aim to also measure other elemental concentrations (e.g. Li, Ba, Mn) and further expand on our preliminary data.

\section{Conclusion}

This chapter shows that archaeological shell midden sites, in particular sites in the southern Red Sea coast, have considerable potential for interdisciplinary research, involving archaeology, biology, and palaeoclimatic reconstruction. Specifically, they would have provided a focus point for African-Arabian coastal populations.

The stable isotope composition of $C$. fasciatus shells found within the shell midden sites provides a high-resolution record of the local marine environment from modern times until the mid-Holocene. Elemental shell records provided by LIBS showed no obvious environmental control on $\mathrm{Mg} / \mathrm{Ca}$ and $\mathrm{Sr} / \mathrm{Ca}$ ratios. Future analyses should aim to employ more comprehensive modern data as well as a larger variety of elemental ratios. Archaeologically, the Farasan shell middens are a prime example of intensive shellfish exploitation, where there are shell mounds of up to several metres in height that accumulated within only a few centuries. The shells are evidence of the richness of marine landscapes in general and the southern Red Sea

At present the growing industry and population of the Farasan islands pose a threat to the preservation of these shell mounds. To further exploit these rich archives of prehistoric life in the southern Red Sea region it is becoming increasingly important to protect these archaeological sites.

\section{Acknowledgments}


We greatly thank Najeeb Rasul for organising the meeting in Jeddah and for his help with the publication of this chapter. Research on the Farasan Islands has been made possible through the support and collaboration of the Saudi Commission for Tourism and National Heritage (SCTH), in particular its President, HRH Prince Sultan bin Salman bin AbdulAziz al Saud, Professor Ali Al-Ghassan, and Jamal Omar. Underwater work on modern shells has been supported by permits from the Department of General Survey of the Ministry of Defense. The work has been supported by grants from the European Research Council (Advanced Grant 269586 DISPERSE under the 'Ideas' Specific Programme of FP7), and EU Marie-Curie Action, "Intra-European Fellowships for Career Development'” (Archaeological and climatic data from elemental ratios using rapid analysis of shell carbonate - ACCELERATE). The research has greatly benefited from comments and discussions with Geoff Bailey, Robyn Inglis, Matthew Meredith-Williams, Harry Robson, Andre Colonese, Demetrios Anglos, Panayiotis Siozos and Costas Fotakis. This is DISPERSE contribution no. 38.

\section{References}

Adamson DA, Gasse F, Street FA, Williams MAJ (1980) Late Quaternary history of the Nile. Nature 288:50-55

Alsharekh A, Bailey G (2014) Coastal Prehistory in Southwest Arabia and the Farasan Islands: 2004-2009 Field Investigations. Saudi Commission for Tourism and Antiquities, Riyadh

Andrus CFT (2011) Shell midden sclerochronology. Quaternary Science Reviews, 30(21): 2892-2905

Arz HW, Lamy F, Pätzold J, Muller PJ, Prins M (2003) Mediterranean moisture source for an early-Holocene humid period in the northern Red Sea. Science 300:118-121

Bailey GN (2004) World prehistory from the margins: the role of coastlines in human evolution. J Interdisciplinary Studies History Archaeology 1:39-50

Bailey GN, Craighead AS (2003) Late Pleistocene and Holocene coastal palaeoeconomies: A reconsideration of the molluscan evidence from northern Spain. Geoarchaeology 18:175-204 
Bailey GN, King GCP (2011) Dynamic landscapes and human dispersal patterns: tectonics, coastlines, and the reconstruction of human habitats. Quatern Sci Rev 30:1533-1553

Bailey GN, Flemming NC, King GCP, Lambeck K, Momber G, Moran LJ, Al-Sharekh A, Vita-Finzi C (2007) Coastlines, submerged landscapes, and human evolution: The Red Sea Basin and the Farasan Islands. J Island Coastal Archaeology 2:127-160

Bailey GN, Meredith-Williams M, Alsharekh AM (2013) Shell mounds of the Farasan Islands, Saudi Arabia. In: Bailey GN, Hardy K, Camara A (eds) Shell Energy. pp $241-254$

Bailey GN, Alsharekh A, Flemming NC, Momber G, Moran LJ, Sinclair A, King GCP, VitaFinzi C, Al-Ma’Mary A, AlShaikh NY, AlGhamdi S (2014a) Coastal archaeology and prehistory in the Southwest Region of Saudi Arabia and the Farasan Islands: report on the 2004 and 2006 surveys of the joint Saudi-UK Southern Red Sea Project. In: Alsharekh A, Bailey GN (eds) Coastal Prehistory in Southwest Arabia and the Farasan Islands - 2004-2009 Field investigations, 16-74

Bailey GN, Alsharekh A, Momber G, Moran LJ, Williams MGW, Satchell JS, Gillespie J, Reeler C, AlShaikh N, Robson H (2014b) Coastal archaeology in the Farasan Islands: report on the 2009 fieldwork of the joint Saudi-UK Southern Red Sea Project. In: Alsharekh A, Bailey GN (eds) Coastal Prehistory in Southwest Arabia and the Farasan Islands - 2004-2009 Field investigations, 160-215

Bailey GN, Meredith-Williams M, Alsharekh A, Hausmann N (this volume) The archaeology of Pleistocene coastal environments and human dispersals in the Red Sea: insights from the Farasan Islands

Bicho N, Haws J (2008) At the land's end: Marine resources and the importance of fluctuations in the coastline in the prehistoric hunter-gatherer economy of Portugal. Quatern Sci Rev 27:2166-2175

Biton E, Gildor H, Trommer G, Siccha M, Kucera M, van der Meer MTJ, Schouten S (2010) Sensitivity of Red Sea circulation to monsoonal variability during the Holocene: An integrated data and modeling study. Paleoceanography 25:PA4209

Cáceres, JO, Pelascini F, Motto-Ros V, Moncayo S, Trichard F, Panczer G, Marín-Roldán A, Cruz JA, Coronado I and Martín-Chivelet J (2017) Megapixel multi-elemental 
imaging by Laser-Induced Breakdown Spectroscopy, a technology with considerable potential for paleoclimate studies. Scientific Reports 7, 1: 5080

Clark ID, Fritz P (1997) Environmental Isotopes in Hydrogeology. Lewis Publishers, Boca Raton, FL

Cobo A, García-Escárzaga A, Gutiérrez-Zugasti I, Setién J, González-Morales MR and López-Higuera JM (2017) Automated measurement of magnesium/calcium ratios in gastropod shells using laser-induced breakdown spectroscopy for paleoclimatic applications. Applied spectroscopy 71,4: 591-599

Cortés-Sánchez M, Morales-Muñiz A, Simón-Vallejo MD, Lozano-Francisco MC, VeraPeláez JL, Finlayson C, Rodríguez-Vidal J, Delgado-Huertas A, Jiménez-Espejo FJ, Martínez-Ruiz F and Martínez-Aguirre MA (2011). Earliest known use of marine resources by Neanderthals. PLoS ONE 6(9):e24026

Crassard R, McCorriston J, Oches E, 'abd Al-Aziz Bin A, Espagne J, Sinnah M ( 2006) Manayzah, early to mid-Holocene occupations in Wādī Șanā (Haḍramawt, Yemen). In: Proceedings of the Seminar for Arabian Studies 36:151-173

Crenshaw MA (1980) Mechanisms of shell formation and dissolution. In: Rhoads DC, Lutz RA (eds) Skeletal Growth of Aquatic Organisms. Plenum Publishing Corporation, New York, 115-132

Cusack M and Freer A (2008). Biomineralization: elemental and organic influence in carbonate systems. Chemical reviews, 108(11): 4433-4454

Dettman DL, Reische AK, Lohmann KC (1999) Controls on the stable isotope composition of seasonal growth bands in aragonitic fresh-water bivalves (Unionidae). Geochim Cosmochim Acta 63:1049-1057

Durham, SR, Gillikin, DP, Goodwin, DH and Dietl GP (2017). Rapid determination of oyster lifespans and growth rates using LA-ICP-MS line scans of shell $\mathrm{Mg} / \mathrm{Ca}$ ratios. Palaeogeography, Palaeoclimatology, Palaeoecology. DOI: 10.1016/j.palaeo.2017.06.013

Edens C, Wilkinson TJ (1998) Southwest Arabia during the Holocene: Recent archaeological developments. J World Prehistory 12:55-119 
Elderfield, $\mathrm{H}$ and Ganssen G (2000) Past temperature and $\delta^{18} \mathrm{O}$ of surface ocean waters inferred from foraminiferal $\mathrm{Mg} / \mathrm{Ca}$ ratios. Nature, 405(6785):442.

Erlandson JM (2001) The archaeology of aquatic adaptations: paradigms for a new millennium. Journal of Archaeological Research 9: 287-350

Erlandson JM, Moss ML, Des Lauriers M (2008) Life on the edge: early maritime cultures of the Pacific Coast of North America. Quatern Sci Rev 27:2232-2245

Ferguson JE, Henderson GM, Fa DA, Finlayson JC, Charnley NR (2011) Increased seasonality in the Western Mediterranean during the last glacial from limpet shell geochemistry. Earth Planet Sci Lett 308:325-333

Finlayson C (2008) On the importance of coastal areas in the survival of Neanderthal populations during the Late Pleistocene. Quatern Sci Rev 27:2246-2252

Finstad KM, Ingram BL, Schweikhardt P, Lightfoot KG, Luby EM, Coles GR (2013) New insights about the construction and use of shell mounds from the geochemical analysis of mollusks: an example from the greater San Francisco Bay. J Archaeological Sci $40: 2648-2658$

Fleitmann D, Burns SJ, Mangini A, Mudelsee M, Kramers J, Villa I, Neff U, Al-Subbary AA, Buettner A, Hippler D, Matter A (2007) Holocene ITCZ and Indian monsoon dynamics recorded in stalagmites from Oman and Yemen (Socotra). Quatern Sci Rev $26: 170-188$

Flemming NC, Bailey GN, Courtillot V, King G, Lambeck K, Ryerson F, Vita-Finzi C (2003) Coastal and marine palaeo-environments and human dispersal points across the Africa-Eurasia boundary. In: Brebbia CA, Gambin T (eds) The maritime and underwater heritage. Wessex Institute of Technology, Southampton, pp 61-74

Füllenbach CS, Schöne BR, Mertz-Kraus R (2015) Strontium/lithium ratio in aragonitic shells of Cerastoderma edule (Bivalvia) - A new potential temperature proxy for brackish environments. Chem Geol 417:341-355

Freitas P, Clarke LJ, Kennedy H, Richardson C and Abrantes F (2005) Mg/Ca, $\mathrm{Sr} / \mathrm{Ca}$, and stable-isotope ( $\delta 18 \mathrm{O}$ and $\delta 13 \mathrm{C}$ ) ratio profiles from the fan mussel Pinna nobilis: Seasonal records and temperature relationships. Geochemistry, Geophysics, 
Geosystems 6, no. 4. doi:10.1029/2004GC000872

Gasse F (2000) Hydrological changes in the African tropics since the Last Glacial Maximum. Quatern Sci Rev 19:189-211

Giakoumaki, A, Melessanaki, K and Anglos D (2007). Laser-induced breakdown spectroscopy (LIBS) in archaeological science-applications and prospects. Analytical and bioanalytical chemistry, 387(3):749-760

Graniero, LE, Surge D, Gillikin DP, Briz i Godino I and Álvarez M (2017) Assessing elemental ratios as a paleotemperature proxy in the calcite shells of patelloid limpets. Palaeogeography, Palaeoclimatology, Palaeoecology465 (2017): 376-385

Grossman EL and Ku TL (1986) Oxygen and carbon isotope fractionation in biogenic aragonite: temperature effects. Chem Geology 59:59-74

Harmon RS, De Lucia FC, Miziolek AW, McNesby KL, Walters RA, French PD (2005) Laser-induced breakdown spectroscopy (LIBS) - an emerging field-portable sensor technology for real-time, in-situ geochemical and environmental analysis. Geochemistry: Exploration, Environment, Analysis 5:21-28

Harrower MJ (2008) Hydrology, ideology, and the origins of irrigation in ancient southwest. Arabia. Curr Anthropol 49:497-510

Hausmann N (2015) The shell mounds of the Farasan Islands - An isotopic study of seasonality and coastal exploitation. Doctoral Dissertation, University of York

Hausmann N, Meredith-Williams M (2016a). Exploring accumulation rates of shell deposits through seasonality data. J Archaeol Method Theory. doi:10.1080/15564894.2016.1216478

Hausmann N, Meredith-Williams M (2016b) Seasonal patterns of coastal exploitation on the Farasan Islands, Saudi Arabia. J Island Coastal Archaeology. doi:10.1007/s10816016-9287-x

Hausmann N, Colonese AC, de Lima Ponzoni A, Hancock Y, Meredith-Williams M, Leng MJ, Bailey GN (2015a) Isotopic composition of Conomurex fasciatus shells as an environmental proxy for the Red Sea. Quat Int. doi:10.1016/j.quaint.2015.08.051

Hausmann N, Meredith-Williams M, Bailey G (2015b) Results of recent excavations on the 
Farasan Islands and studies of large-scale prehistoric shellfish gathering in the Red Sea. In: Bicho N, Detry C, Price TD, Cunha E (eds) Muge 150th: The 150th Anniversary of the Discovery of Mesolithic Shell middens. Cambridge Scholars Publishing, 301-314

Hausmann N, Siozos P, Lemonis A, Colonese AC, Robson HK \& Anglos D (2017) Elemental mapping of $\mathrm{Mg} / \mathrm{Ca}$ intensity ratios in marine mollusc shells using laserinduced breakdown spectroscopy. J. Anal. At. Spectrom. 32:1467-1472

Hoelzmann P, Jolly D, Harrison SP, Laarif F, Bonnefille R, Pachur HJ (1998) Mid-Holocene land-surface conditions in northern Africa and the Arabian Peninsula: A data set for the analysis of biogeophysical feedbacks in the climate system. Global Biogeochemical Cycles 12(1):35-51

Jerardino A (2013) Mega shell middens and hunter-gatherer resource intensification along the west coast of South Africa. In: Bailey G, Hardy K, Camara A (eds) Shell Energy, 207-228

Jew NP, Erlandson JM, Watts J, White FJ (2013) Shellfish, seasonality, and stable isotope sampling: $\delta^{18} \mathrm{O}$ analysis of mussel shells from an 8,800-year-old shell midden on California's Channel Islands. J Island Coastal Archaeology 8(2):170-189

Jew NP, Erlandson JM, Rick TC, Reeder-Myers L (2014) Oxygen isotope analysis of California mussel shells: seasonality and human sedentism at an 8,200-year-old shell midden on Santa Rosa Island, California. Archaeological Anthropological Sci 6(3):293-303

Jones DS, Arnold B, Quitmyer I, Schöne BR, Surge D (2007) First International Sclerochronology Conference. http://conference.ifas.ufl.edu/sclerochronology [Accessed 25 September 2016]

Kastner M 1999. Oceanic minerals: their origin, nature of their environment and significance. Proceedings of the National Academy of Sciences 96:3380-3387

Kennish M (1980) Shell microgrowth analysis, Mercenaria mercenaria as a type example for research in population dynamics. In: Rhoads D, Lutz R (eds) Skeletal growth of aquatic organisms. Plenum Publishing Corporation, New York, 255-294 
Khalidi L (2005) The prehistoric and early historic settlement patterns on the Tihāmah coastal plain (Yemen): preliminary findings of the Tihāmah Coastal Survey 2003. Proceedings of the Seminar for Arabian Studies 35:115-127

Leng MJ and Lewis JP (2016). Oxygen isotopes in Molluscan shell: applications in environmental archaeology. Environmental Archaeology, 21(3), 295-306

Lazareth, CE, Le Cornec F, Candaudap F and Freydier R (2013) Trace element heterogeneity along isochronous growth layers in bivalve shell: consequences for environmental reconstruction. Palaeogeography, Palaeoclimatology, Palaeoecology, 373:39-49

Lézine AM, Robert C, Cleuziou S, Inizan ML, Braemer F, Saliège JF, Sylvestre F., Tiercelin JJ, Crassard R, Méry S. and Charpentier V. (2010). Climate change and human occupation in the Southern Arabian lowlands during the last deglaciation and the Holocene." Global and Planetary Change 72(4): 412-428

Lézine AM, Bassinot F, Peterschmitt JY (2014) Orbitally-induced changes of the Atlantic and Indian monsoons over the past 20,000 years: New insights based on the comparison of continental and marine records. Bull Soc Geol Fr 185:3-12

Lutz RA and Rhoads DC (1977) Anaerobiosis and a theory of growth line formation, Science, 198:1222-1227

Marean CW (2014) The origins and significance of coastal resource use in Africa and Western Eurasia. J Hum Evol 77:17-40

Marín-Roldán A, Cruz JA, Martín-Chivelet J, Turrero MJ, Ortega AI, Cáceres J (2014) Evaluation of Laser Induced Breakdown Spectroscopy (LIBS) for detection of trace element variation through stalagmites: potential for paleoclimate series reconstruction. J Applied Laser Spectroscopy 1:7-12

Martin L, McCorriston J, Crassard R (2009). Early Arabian pastoralism at Manayzah in Wādī Șanā, Haḍramawt. Proceedings of the Seminar for Arabian Studies 39:271-282

McCorriston J (2013) Pastoralism and pilgrimage. Curr Anthropol 54:607-641

McCorriston J, Harrower M, Martin L, Oches E (2012) Cattle cults of the Arabian Neolithic and early territorial societies. Am Anthropol 114:45-63

McCorriston J, Harrower M, Oches E, 'Aqil AB, Heyne C, Noman A, Crassard R, 
BaDhofary K, Anderson J (2005) Foraging economies and population in the Middle Holocene highlands of southern Yemen. Proceedings of the Seminar for Arabian Studies 35:143-154

McCorriston J, Oches EA, Walter DE, Cole Kl (2002) Holocene paleoecology and prehistory in highland southern Arabia. Paleo 28:61-88

Meredith-Williams M, Hausmann N, Bailey GN, King GCP, Alsharekh A, Ghamdi S, Inglis RH (2014a) Mapping, modelling and predicting prehistoric coastal archaeology in the southern Red Sea using new applications of digital-imaging techniques. World Archaeol 46:10-24

Meredith-Williams M, Hausmann N, Inglis R, Bailey G (2014b) 4200 new shell mound sites in the southern Red Sea. In: Fernandes R, Meadows J (eds) Human Exploitation of Aquatic Landscapes. Special Issue, Internet Archaeology. doi:10.11141/ia.37.2

Milano S, Prendergast AL, Schöne BR (2016) Effects of cooking on mollusk shell structure and chemistry: Implications for archeology and paleoenvironmental reconstruction. $\mathrm{J}$ Archaeological Sci: Reports 7:14-26

Momber G (2000) Drowned and deserted: a submerged prehistoric landscape in the Solent, England. Internat J Nautical Archaeology 29:86-99

Momber G (2004) The inundated landscapes of the western Solent. In: Flemming NC (ed) Submarine prehistoric archaeology of the North Sea: research priorities and collaboration with industry. London: CBA Research Report 141:37-42

Momber G, Sakellariou D, Bailey GN, Rousakis G (this volume) The multi-disciplinary search for underwater archaeology in the southern Red Sea

Pachur HJ, Kröpelin S (1987) Wadi Howar: paleoclimatic evidence from an extinct river system in the southeastern Sahara. Science 237:298-300

Poulain C, Gillikin DP, Thébault J, Munaron JM, Bohn M, Robert R, Paulet YM, Lorrain A (2015) An evaluation of $\mathrm{Mg} / \mathrm{Ca}, \mathrm{Sr} / \mathrm{Ca}$, and $\mathrm{Ba} / \mathrm{Ca}$ ratios as environmental proxies in aragonite bivalve shells. Chemical Geology 396:42-50

Qiao S, Ding Y, Tian D, Yao L, Yang G (2015) A review of laser-induced breakdown spectroscopy for analysis of geological materials. Applied Spectroscopy Rev 50:1-26

Raitsos DE, Pradhan Y, Brewin RJW, Stenchikov G, Hoteit I (2013) Remote sensing the 
phytoplankton seasonal succession of the Red Sea. PLoS ONE 8:e64909

Ridgway ID, Richardson CA and Austad SN (2010) Maximum shell size, growth rate, and maturation age correlate with longevity in bivalve molluscs. Journals of Gerontology Series A: Biomedical Sciences and Medical Sciences, 66(2): 183-190.

Rosenthal Y, Linsley B (2006) Mg/Ca and Sr/Ca paleothermometry from calcareous marine fossils. In: Elias S (ed) Encyclopedia of Quaternary Sciences. Elsevier, London, pp $1723-1731$

Rossignol-Strick M (1985). Mediterranean Quaternary sapropels, an immediate response of the African monsoon to variation of insolation. Palaeogeogr Palaeoclimatol Palaeoecol 49:237-263

Rossignol-Strick M (1983) African monsoons, an immediate climate response to orbital insolation. Nature 304:46-49

Sand KK, Rodriguez-Blanco JD, Makovicky E, Benning LG, Stipp SLS (2012) Crystallization of $\mathrm{CaCO} 3$ in water-alcohol mixtures: Spherulitic growth, polymorph stabilization, and morphology change. Cryst Growth Des 12:842-853

Schöne BR (2008) The curse of physiology - challenges and opportunities in the interpretation of geochemical data from mollusk shells. Geo-Marine Letters 28:269285

Schöne, B.R. and Gillikin, D.P., 2013. Unraveling environmental histories from skeletal diaries — advances in sclerochronology. Palaeogeography, Palaeoclimatology, Palaeoecology, 373:1-5

Schöne BR, Zhang Z, Jacob D, Gillikin DP, Tütken T, Garbe-Schönberg D, Soldati A (2010) Effect of organic matrices on the determination of the trace element chemistry $(\mathrm{Mg}$, $\mathrm{Sr}, \mathrm{Mg} / \mathrm{Ca}, \mathrm{Sr} / \mathrm{Ca}$ ) of aragonitic bivalve shells (Arctica islandica) - comparison of ICP-OES and LA-ICPMS data. Geochemical J 44:23-37

Sharabati D (1984) Red Sea shells. Routledge and Kegan Paul Plc, London

Shirai K, Schöne BR, Miyaji T, Radermacher P, Krause RA, Tanabe K (2013) Assessment of the mechanism of elemental incorporation into bivalve shells (Arctica islandica) based on elemental distribution at the microstructural scale. Geochimt Cosmochim Acta 
$126: 1-39$

Sirocko F, Sarnthein M, Erlenkeuser H, Lange H, Arnold M, Duplessy JC (1993) Centuryscale events in monsoonal climate over the past 24,000 years. Nature 364:322-324

Steele TE and Klein RG (2008) Intertidal shellfish use during the Middle and Later Stone Age of South Africa. Archaeofauna 17:63-76

Stein JK, Deo JN and Phillips LS (2003) Big sites — short time: accumulation rates in archaeological sites. Journal of Archaeological Science, 30(3):297-316

Surge D, Lohmann KC (2008) Evaluating $\mathrm{Mg} / \mathrm{Ca}$ ratios as a temperature proxy in the estuarine oyster, Crassostrea virginica. J Geophys Res: Biogeosciences 113, G02001. doi:10.1029/2007JG000623

Thomas KD (2015a) Molluscs emergent, Part I: themes and trends in the scientific investigation of mollusc shells as resources for archaeological research. $\mathrm{J}$ Archaeological Sci 56:133-140

Thomas KD (2015b) Molluscs emergent, Part II: themes and trends in the scientific investigation of molluscs and their shells as past human resources. J Archaeological Sci 56:159-167

Van Campo E, Duplessy JC, Rossignol-Strick M (1982) Climatic conditions deduced from a 150-kyr oxygen isotope-pollen record from the Arabian Sea. Nature 296:56-59

Van Rampelbergh M, Fleitmann D, Verheyden S, Cheng H, Edwards L, De Geest P, De Vleeschouwer D, Burns SJ, Matter A, Claeys P, Keppens E (2013) Mid- to late Holocene Indian Ocean Monsoon variability recorded in four speleothems from Socotra Island, Yemen. Quat Sci Rev 65:129-142

Wanamaker AD, Kreutz KJ, Borns HW, Introne DS, Feindel S, Funder S, Rawson PD and Barber BJ (2007). Experimental determination of salinity, temperature, growth, and metabolic effects on shell isotope chemistry of Mytilus edulis collected from Maine and Greenland. Paleoceanography, 22(2): PA2217

Wanamaker AD, Kreutz KJ, Wilson T, Borns HW, Introne DS, Feindel S (2008) Experimentally determined $\mathrm{Mg} / \mathrm{Ca}$ and $\mathrm{Sr} / \mathrm{Ca}$ ratios in juvenile bivalve calcite for Mytilus edulis: Implications for paleotemperature reconstructions. Geo-Marine 
Letters 28:359-368

Warter V and Müller W (2017) Daily growth and tidal rhythms in Miocene and modern giant clams revealed via ultra-high resolution LA-ICPMS analysis-A novel methodological approach towards improved sclerochemistry. Palaeogeography, Palaeoclimatology, Palaeoecology, 465:362-375.

Watanabe T, Winter A and Oba T (2001) Seasonal changes in sea surface temperature and salinity during the Little Ice Age in the Caribbean Sea deduced from $\mathrm{Mg} / \mathrm{Ca}$ and ${ }^{18}$ $\mathrm{O} /{ }^{16} \mathrm{O}$ ratios in corals. Marine Geology, 173(1):21-35.

Woodman P (2013) Shell Energy: an overview. In: Bailey G, Hardy K, Camara A (eds) Shell Energy. pp 299-308

Zazzo A, Munoz O, Saliège JF (2014) Diet and mobility in a late Neolithic population of coastal Oman inferred from radiocarbon dating and stable isotope analysis. Am J Physical Anthropology 153:353-364 


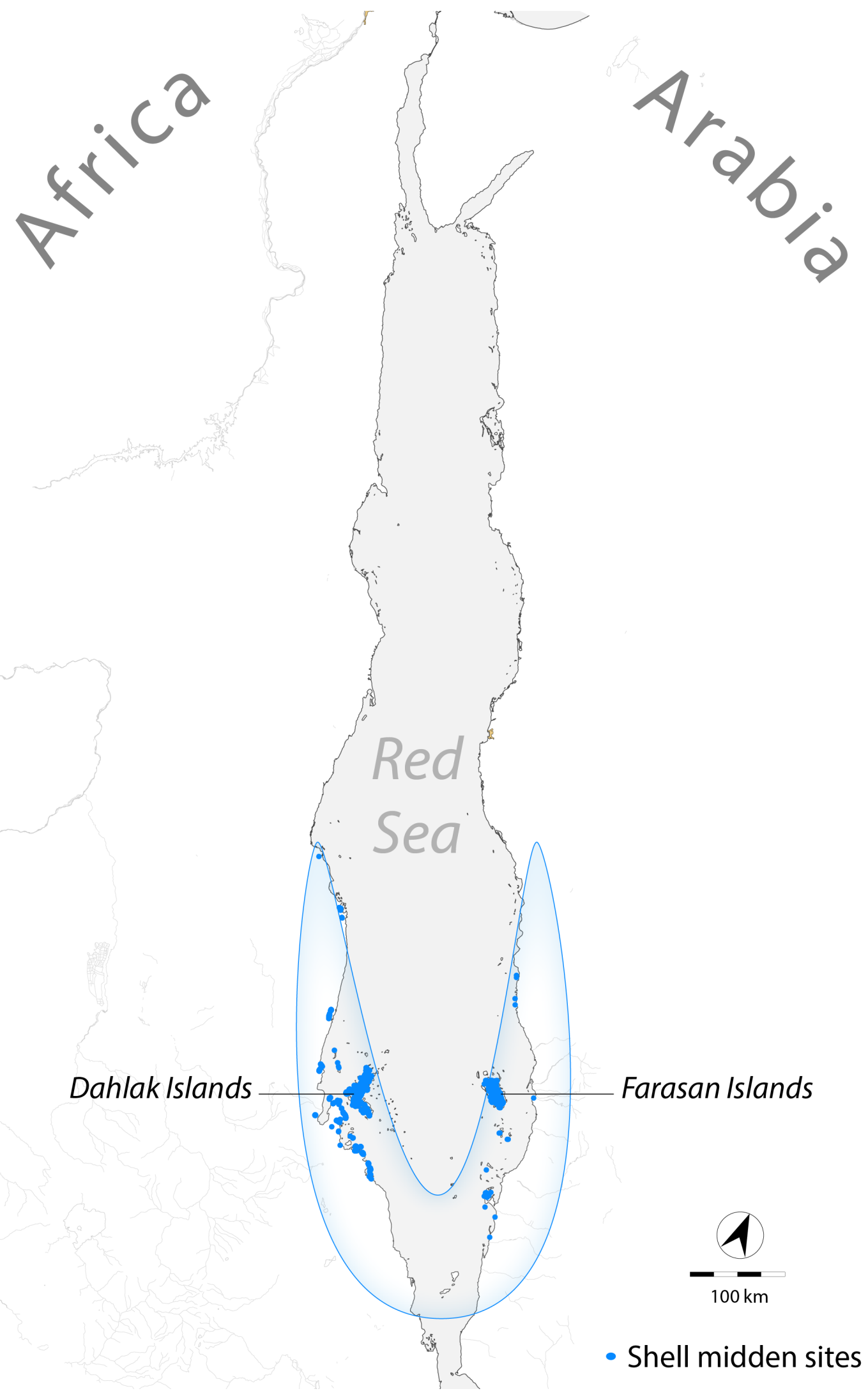

Figure 1. Locations of shell midden sites in the southern Red Sea. Highlighted area indicating region of intense marine exploitation. 


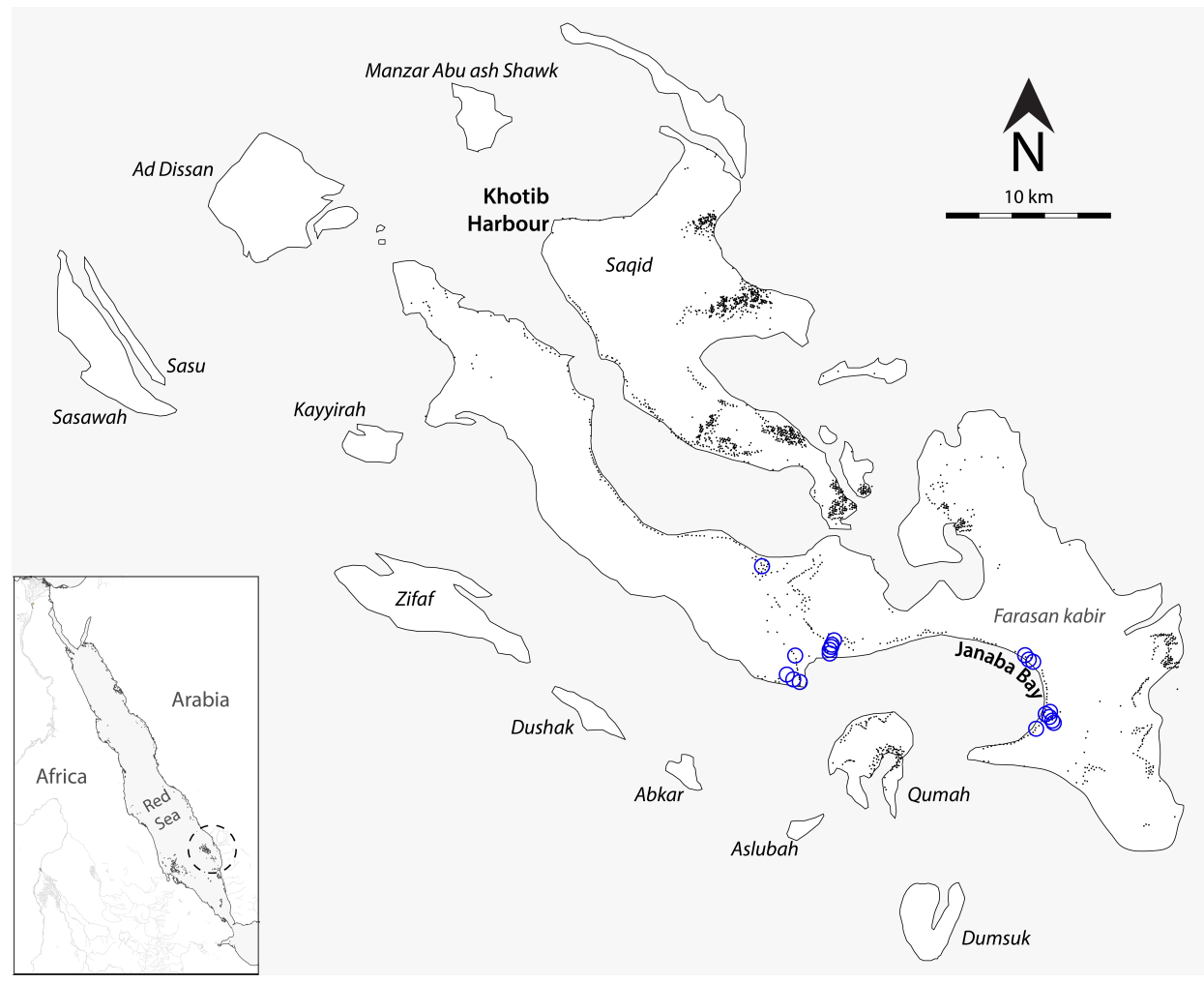

Figure 2. Locations of excavated (blue circles) and unexcavated (black dots) shell middens on the Farasan Islands.

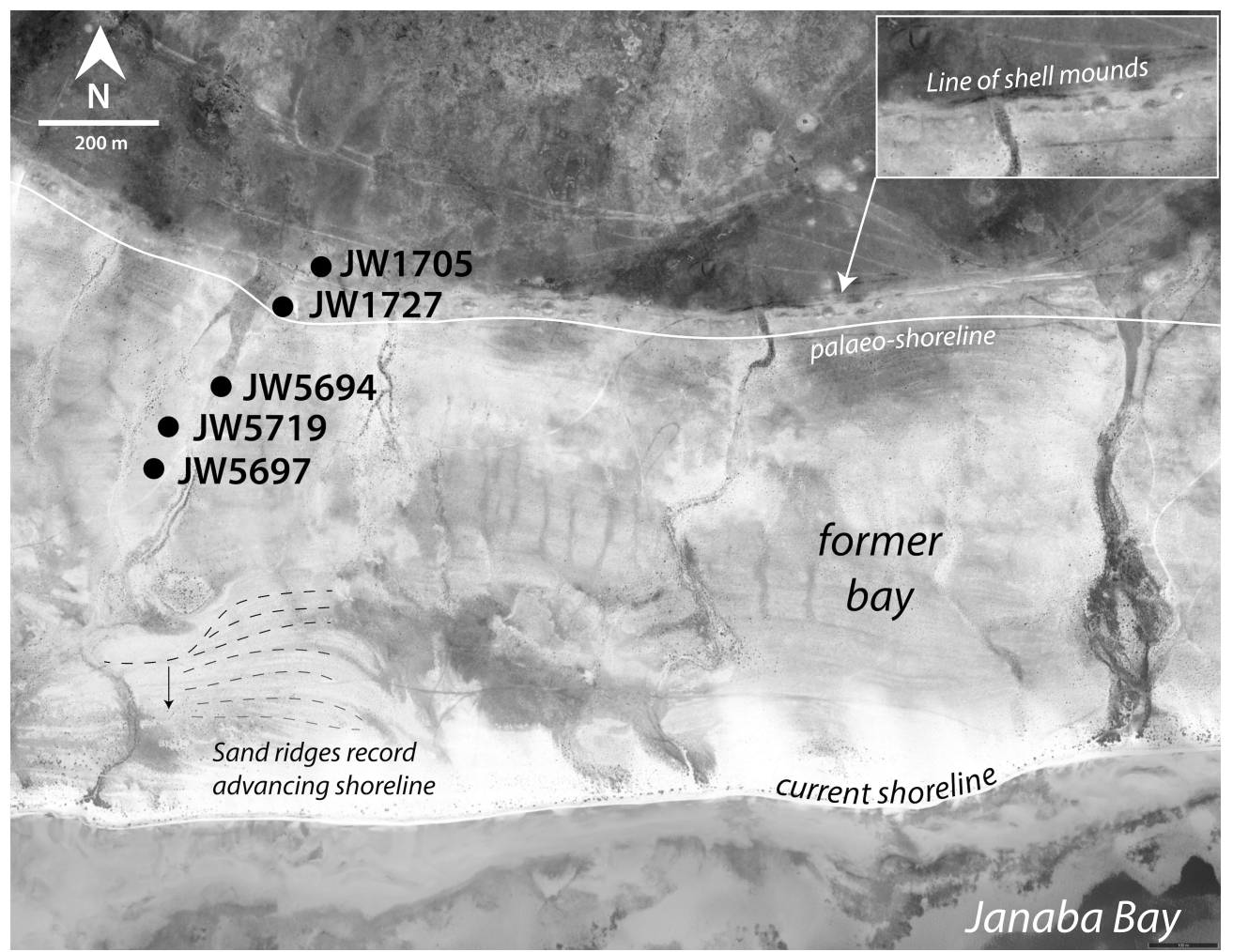

Figure 3. Transect of shell mounds across Janabay Bay palaeo-shoreline, with younger shell mounds closer to and older shell mounds farther from the current shoreline. 


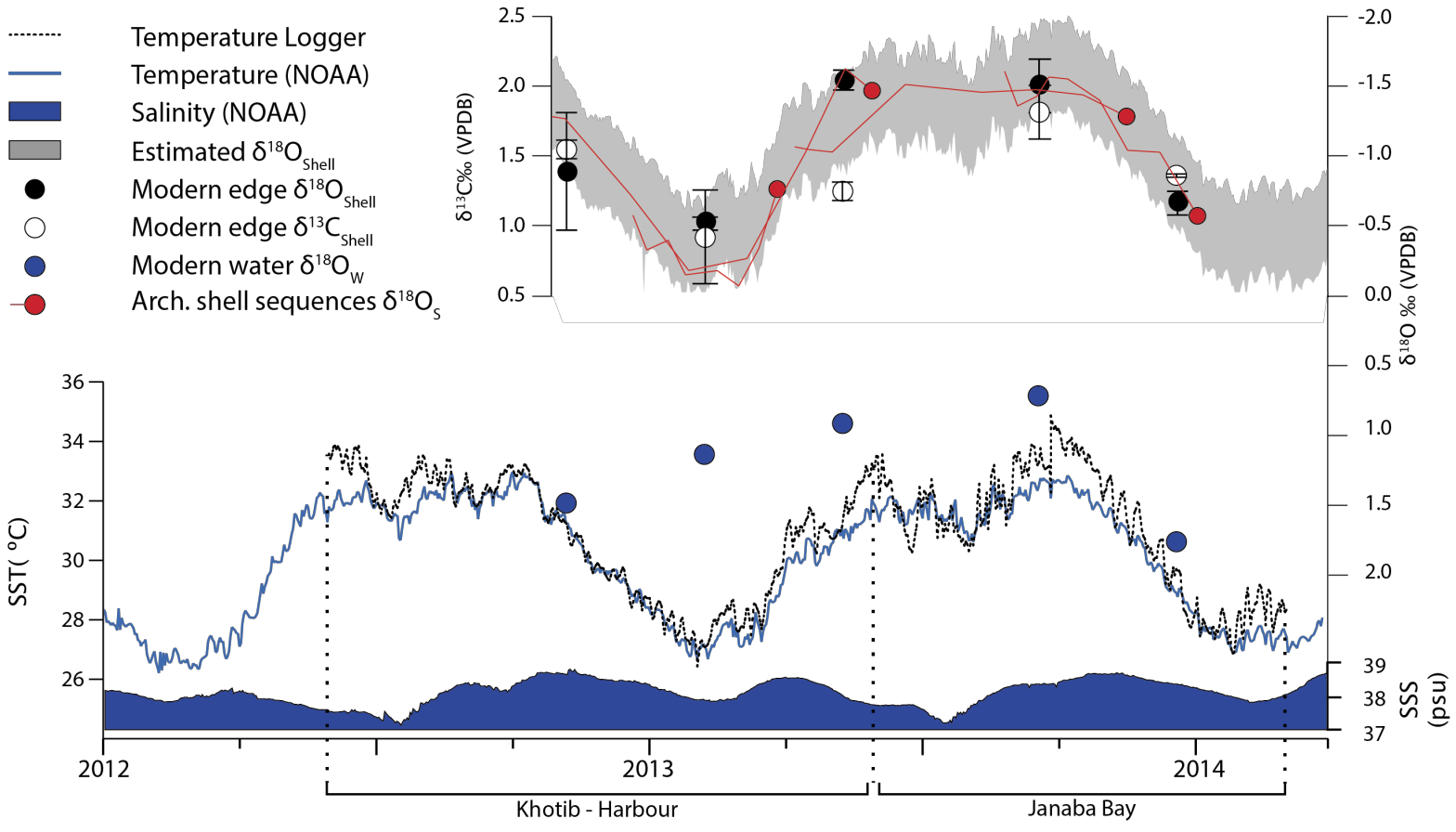

Figure 4. Seasonal change of temperature and salinity with corresponding stable isotope values $\left(\delta^{18} \mathrm{O}\right.$ in black and $\delta^{13} \mathrm{C}$ in white) measured in shell carbonate of $C$. fasciatus and in $\delta^{18} \mathrm{O}$ water samples (blue) as well as the estimated $\delta^{18} \mathrm{O}$ for each season (grey area).

Sequential $\delta^{18} \mathrm{O}$ values from archaeological shells as examples for determining season of death (red line, circle for terminal value).
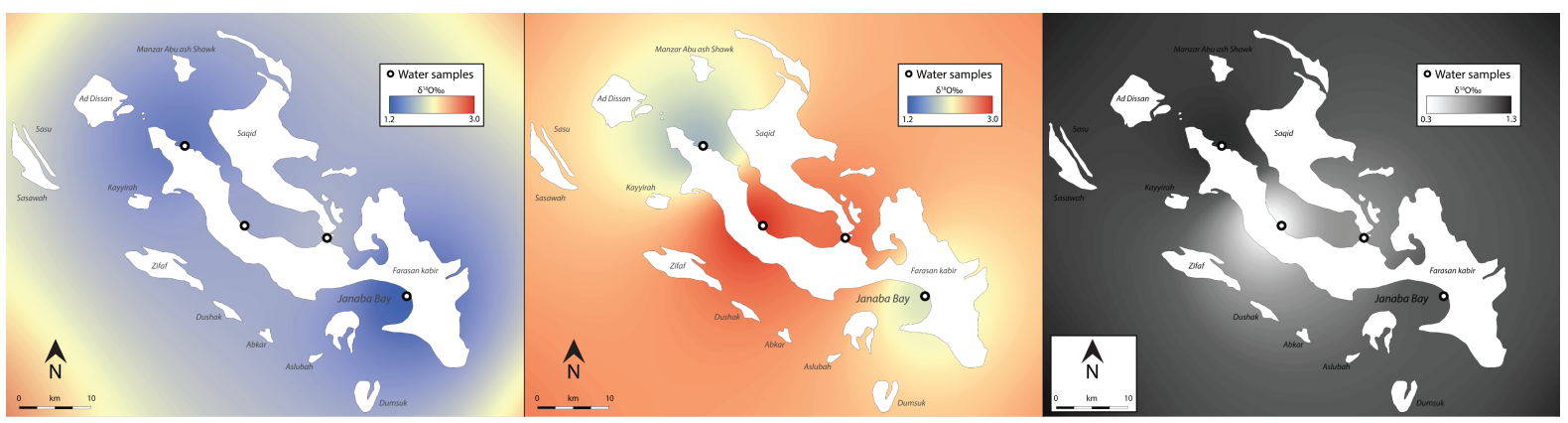

Figure 5. Spatial distribution of $\delta^{18} \mathrm{O}_{\mathrm{W}}$ values in spring (left) and autumn (centre). Difference between seasons is most visible in the sample areas between the two large islands (Farasan Kabir and Saqid). Their sheltered location causes little water exchange with the Red Sea and makes the impact of evaporation fractionation during summer more apparent. 

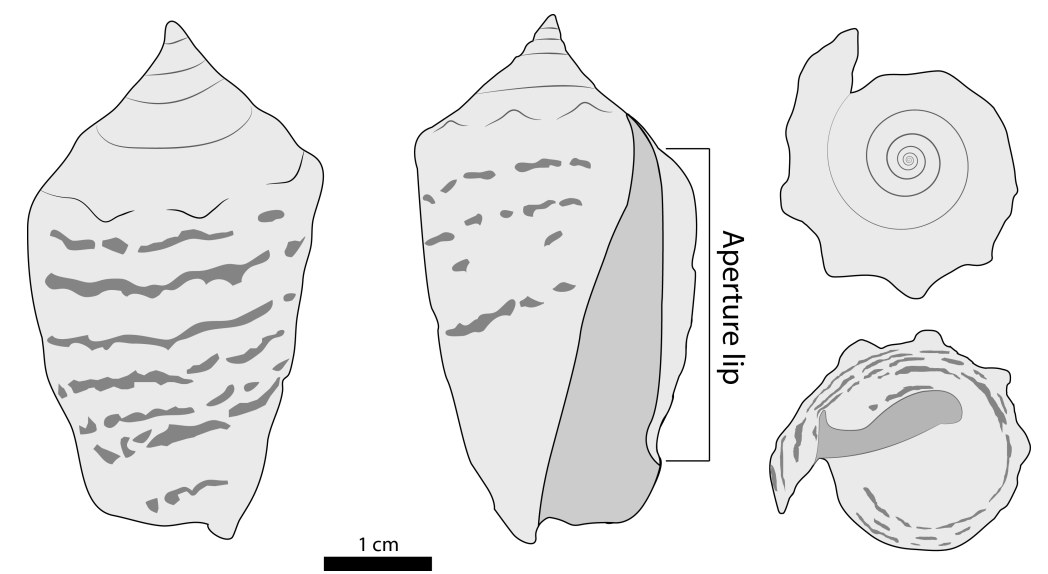

Figure 6. Adult specimen of C. fasciatus shell with location of aperture lip.

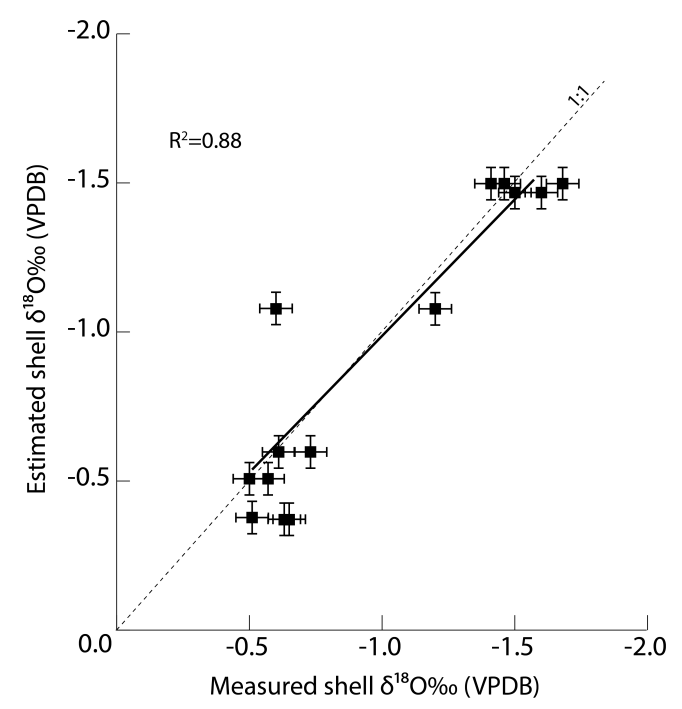

Figure 7. Correlation of measured shell edge values $\delta^{18} \mathrm{O}_{\mathrm{S}}$ vs. estimated values $\delta^{18} \mathrm{O}_{\text {Est }}$, indicating that all major factors controlling the isotopic composition of $\mathrm{C}$. fasciatus are accounted for. 



Figure 8. Seasonality results of analysed layers in JW1727 by layer and location within layer (top, centre, base). Note the gradual change in season with a change in stratigraphic sequence in layer 8 . 

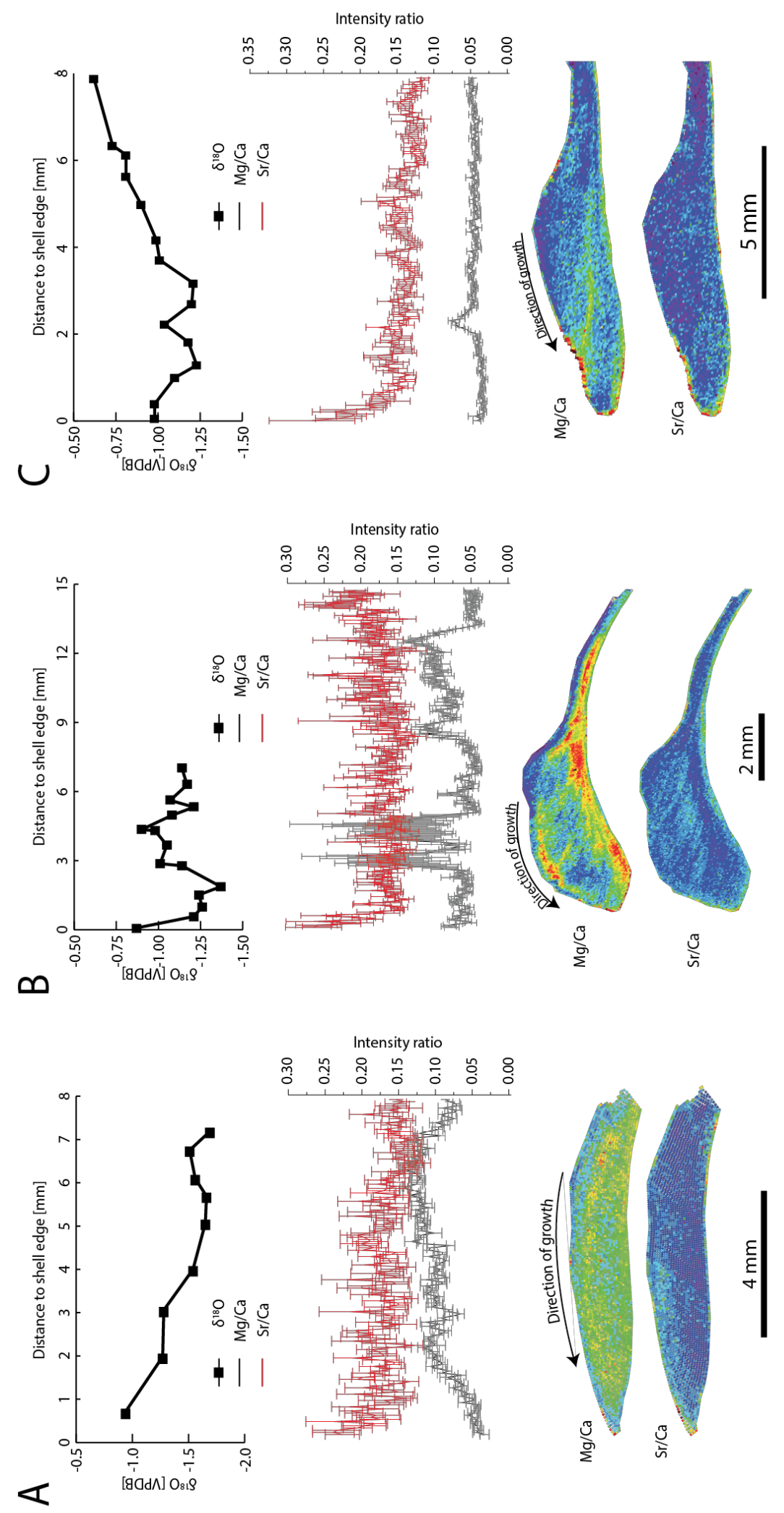

Figure 9. Comparison of sequential $\delta^{18} \mathrm{O}$ values from archaeological shells with line scans and maps of $\mathrm{Mg} / \mathrm{Ca}$ and $\mathrm{Sr} / \mathrm{Ca}$ intensity ratios. 